\title{
Nauka o sercu, jako miejscu spotkania Boga i człowieka w nauczaniu świętego Bazylego Wielkiego
}

\author{
Krzysztof Kuderski \\ Chrześcijańska Akademia Teologiczna w Warszawie \\ Polska \\ studentusk@wp.pl
}

\begin{abstract}
Krzysztof Kuderski, A Study of the Heart, as the Meeting Place of God and According to the Teaching of St. Basil the Great, Elpis, 182016 : 75-80.

Abstract: "Heart" is one of the most common words, which often appears in the writings of St. Basil of Caesarea. In his point of view, the heart is the main organ of the human being. It constitutes the centre of emotions and physical strength of life. It is also a symbol of a person's entire internal life. The fullness of spiritual life, which encompasses the whole human being with his thoughts, words and actions is found in the heart. According to the teaching of St. Basil, God enters in a spiritual relationship with man through the heart.

Streszczenie: Serce jest jednym ze słów, które bardzo często pojawia się w pismach świętego Bazylego Wielkiego. W jego ujęciu, serce jest głównym organem w człowieku. Stanowi siedzibę uczuć i fizycznej siły życiowej. Jest symbolem całego wnętrza człowieka. W sercu skupia się pełnia życia duchowego, które ogarnia całego człowieka z jego myślami, słowami oraz działaniami. Według nauki świętego Bazylego, to poprzez serce Bóg wchodzi w duchową relację z człowiekiem.
\end{abstract}

Keywords: God, heart, virtue, human being, soul, sin

Słowa kluczowe: Bóg, serce, cnota, człowiek, dusza, grzech

\section{Wstęp}

Święty Bazyli Wielki (IV wiek), wiele miejsca w swoich dziełach poświęcał człowiekowi a zwłaszcza jego sercu. Uważał on, że celem życia człowieka powinno być zdobywanie cnót chrześcijańskim. Zalecał również, aby życie ludzkie skierowane było na Boga. Pomocnym $\mathrm{w}$ tym procesie było oderwane się od spraw materialnych i przyziemnych. Święty Ojciec Kapadocki opisywał swoje przemyślenia na podstawie przeżyć związanych z życiem monastycznym, które wiódł w klasztorze nad rzeką Irys ${ }^{1}$. Żyjąc w klasztorze uczył się miłości do Boga i bliźnich. Miłość tą dostrzegał w kontekście cnót. Będąc w klasztorze analizował strukturę ludzkiego ciała i jego odniesienie do duszy. Brał pod uwagę zwłaszcza umysł i serce, jako te organy, które pełnią główną rolę w człowieku i zwracają się do Boga. Stwierdzał, że to w sercu za pośrednictwem czynów moralnych dokonuje się doskonalenie się człowieka. Czyny te jednak, poprzedzone są pobożnymi myślami, które mieszczą się w umyśle.

\section{Serce, jako miejsce spotkania Boga i człowieka}

Święty Bazyli Wielki nauczał, że człowiek wraz z duszą i ciałem został stworzony według obrazu Bożego. Za

Por. F. Drączkowski, Patrologia, Lublin 2012, s. 108. podstawę swojej antropologii uznaje tekst Księgi Rodzaju, mówiący o stworzeniu człowieka "na obraz i podobieństwo Boże" (Rdz 1, 26-28). Święty Bazyli opisywał w swoich traktatach naturę człowieka skupiając się jednocześnie na istotnych organach ludzkiego ciała. Wspominał przede wszystkim o sercu i rozumie, gdyż to one mają decydujący wpływ na życie człowieka. Serce identyfikował on z całą naturą człowieka. Jest to obszar, który nie tylko pełni funkcje w ciele człowieka, ale również odnosi się do Boga. Ojciec Kapadocki w swoich Homiliach $i$ kazaniach na psalmy, dokładnie opisał tą tematykę.

W Homilii o sześciu dniach stworzenia, święty biskup wyraźnie zaznaczał, że stworzenie człowieka odnosiło się do rozumu lub wnętrza ludzkiego: „I tak, w nas jest wewnętrzny człowiek, a my w pewnym sensie jesteśmy podwójni, mówiąc prawdę, jesteśmy istnieniem wewnętrznym. «Ja» - mówimy o człowieku wewnętrznym. To, co znajduje się poza (mną), to nie jest osobiste «ja», ale to jest «moje». Ręka - to nie jest «ja», lecz «ja» to rozumowy początek duszy. Ręka to przecież część ciała człowieka. Dlatego ciało to jakby narzędzie człowieka, narzędzie duszy. Jednym słowem «człowiek» oznacza duszę jako taką"2. Hierarcha stwierdzał, że człowiek składa się z duszy i ciała, a serce jest elementem, który łączy te dwie części.

Василий Великий, Беседь на Шестоднев. Беседа 10 (7), [w:] Творения иже во святыхъ отияа нашего Василия Великаго, Архиепископа Кесарии Каппадокийския, Новый исправленный переводъ Московской Духовной Академии, Томъ II, Книгоиздательство П. П. Сойкина, Москва 2000, s. 35. 
Arcybiskup Cezarei Kapadockiej, opisując człowieka wewnętrznego i mówiąc o sercu, zazwyczaj miał na myśli jego duszę. Dusza, która stara się zbliżyć do Boga, poprzez serce poznaje naturę swojego istnienia. Bazyli Wielki wskazywał na to, że w wielu miejscach Pisma Świętego słowo serce stosowane jest w znaczeniu kierującej części duszy w przeciwstawieniu do słowa „łono”, które oznacza pożądliwą jej część ${ }^{3}$. Serce związane jest z umysłem.

Komentując słowa 33 psalmu Dawida: „Z miejsca, gdzie przebywa, Patrzy na wszystkich mieszkańców ziemi, On, który ukształtował serce każdego z nich" (Ps 33, 14-15), w swych Homiliach i kazaniach na psalmy, zwracał uwagę na zasadnicze miejsce serca w człowieku. Jest to obszar, w którym człowiek wchodzi w relację z Bogiem. W ludzkim sercu widoczne są wszystkie myśli i dążenia człowieka. Są one jednak widoczne tylko dla Boga, Który jako Stwórca interesuje się człowiekiem, którego stworzył z miłości i wchodzi z nim w relację duchową poprzez serce. Jest to jednak możliwe tylko wtedy, kiedy serce zostało przygotowane na taką duchową relację. Przygotowanie to wiąże się z odpowiednią moralnością człowieka. Człowiek powinien porzucić swoje grzeszne przyzwyczajenia, skupić się bardziej na modlitwie i dopuścić do swojego serca Bożą miłość. Bóg ze względu na Swoją miłość do człowieka interesuje się nim i stara się mu pomóc.

Bazyli postrzegał serce, jako „Boże mieszkanie”, w które bez przeszkód spogląda Bóg: „Nie ma żadnej przeszkody oczom Boga. On widzi nie tylko każdego człowieka, ale także dostrzega serce, które stworzył sam, nie dodając do nich niczego złego. Stwórca stworzył człowieka na Swój obraz. Jest on Tym, Który zbawia serca ludzkie. Człowiek jednak, na skutek grzechu, ostatecznie został otoczony cielesnymi namiętnościami. Można dostrzec, że serce jest niejednolite i wieloosobowe, bezczeszcząc jego dobroć i zdolność do-

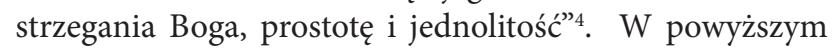
cytacie, symbol serca oznacza człowieka, który jeszcze nie zgrzeszył i przebywał w raju. Natura człowieka, czyli jego serce, zostało stworzone według Bożego obrazu. Oznacza to, że jest ono proste $z$ natury, jednorodne oraz dysponuje zdolnością nawiązania relacji z Panem. Z nauki świętego Bazylego wynika, że obraz Boga w człowieku nie jest pewną dostrzegalną cechą, ale przedstawia „pewne wrodzone dążenia, które uzewnętrzniają się po przez motywację do

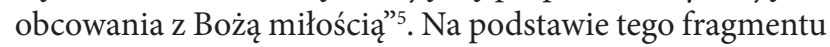
można stwierdzić, że obraz Boży nie jest czymś, co można dostrzec za pomocą wzroku. Nie jest też, czymś powierzchownym. Człowiek poprzez doskonalenie się, dzięki cnotom może w pewien sposób uzewnętrznić ten obraz. Będzie się on przejawiał w gorliwej modlitwie, cnotliwym życiu, zgłębianiu Pisma Świętego oraz zmierzaniu do Boga. Człowiek w tych dążenia nie jest jednak osamotniony. Towarzyszy mu łaska Świętego Ducha.

Ojciec Kapadocki określał Ducha Świętego, jako „spadającą światłość", która dociera do serca i którą przyjmuje

\footnotetext{
Por. Василий Великий. Беседь на Псалмы. Пс. 7(10), [w:] tamże, Москва 2000, s. 55.

4 Tamże, s. 62.

К. Керн, Антропология Св. Григория Паламы, Париж 1950, s. 147.
}

do siebie człowiek sprawiedliwy. Zamieszkujące ludzkie serce uczucia: miłości, radości i pokoju, są „owocami ducha”. Serce odczuwa radość nie w mocy ziemskiego dobrobytu, lecz w mocy ujrzenia Boga i obcowania z Nim. Miłość zbliża duszę z Duchem Świętym. Sama dusza, oswobadza się od namiętności i zwraca się do Ducha: „Nie można zobaczyć obrazu Boga niewidzialnego inaczej, jak tylko w światłości Ducha. A dla tego, kto utkwi wzrok w obrazie, niemożliwe jest oddzielenie światła od obrazu. Ten, który jest przyczyną widzenia, jest widzialny nierozerwalnie z tym, kogo się widzi. Tak więc, dzięki światłości Ducha w sposób właściwy postrzegamy odblask chwały Bożej, przez odbicie zaś jesteśmy doprowadzani do Tego, do Którego należy odbicie i pieczęć tego samego kształtu"6.

W ten sposób, zbliżenie się duszy do Ducha Świętego, odnawia wrażliwość duszy, jej zdolność dostrzegania Boga. Pełnia łaski, wylewana jest przez Ducha Świętego i przyjmowana według wiary człowieka. „Gdy zaś chodzi o uzyskanie przez duszę zażyłości z Duchem, to nie polega ona na przybliżeniu (jakże bowiem mogłoby się zbliżyć to, co jest cielesne, do tego co bezcielesne?), lecz na oddaleniu doznań, które z powodu przywiązania do ciała atakują duszę i pozbawiają ją zażyłości z Bogiem. Tedy więc, oczyściwszy się z brzydoty, którą wycisnęło zło, powróciwszy do naturalnego piękna, tak jak obraz królewski, któremu przez oczyszczenie przywraca się dawną postać - tak jedynie można zbliżyć się do Parakleta"7.

\section{Przemieniająca serce laska Świętego Ducha}

Metamorfoza serca oraz powrót człowieka do niebiańskiego życia i przebywania w Bogu dokonują się mocą Ducha Świętego. Serce człowieka jest „miejscem” działania Ducha Świętego i źródłem łaski dla świata: „Dzięki Niemu serca wznoszą się ku górze, słabi [dają się] prowadzić za rękę, a ci, którzy posuwają się duchowymi istotami dzięki wspólnocie z Nim samym. I podobnie jak ciała jasne i przejrzyste, kiedy pada na nie promień, stają się lśniące i błyszczą innym, choć własnym blaskiem, tak samo dusze niosące Ducha, oświecone przez Ducha, one właśnie stają się duchowe i łaskę przekazują innym. Stąd pochodzi przewidywanie tego, co będzie w przyszłości, rozumienie tajemnic, pojmowanie rzeczy ukrytych, rozdział darów łaski, niebiańskie obywatelstwo, korowód taneczny z aniołami, radość nieskończona, trwanie $\mathrm{w}$ Bogu, podobieństwo do Boga, kraniec wszystkich pragnień, aby stać się Bożym ”8.

Oddziaływanie Świętego Ducha w świecie zachodzi poprzez ludzkie serce. W objaśnieniu Psalmu 44 (Ps 44, 2), święty Bazyli wyjaśniał, że język człowieka sprawiedliwego, kierowany jest Świętym Duchem i „zapisuje słowa Wiecznego Życia” w sercach wierzących. Duch Święty oddziałuje „bardziej lub mniej” według miary czystości, jaką wyznacza

\footnotetext{
6 Bazyli Wielki, O Duchu Świętym, XXVI, 64, [w:] tamże, tłum. A. Brzóstkowska, Warszawa 1999, s. 174

7 Tamże, IX, 23, s. 115.

Tamże, IX, 23, s. 115
} 
serce. Duch Święty w człowieku nie działa nieprzerwanie, leczy tylko wtedy, kiedy działanie człowieka jest odpowiednie do Jego. „Nadto, tak jak w ciele [istnieje] zdrowe, ciepło lub dyspozycje skłaniające do ruchu, tak i w duszy często panuje Duch, ale nie pozostaje On u tych, którzy przez chwiejność usposobienia łatwo odepchnęli łaskę, którą otrzymali; takim był Saul i siedemdziesięciu starszych synów Izraela". Duch Święty działa w człowieku, kiedy ten wykazuje się modlitewną postawą.

Święty Bazyli pisał: „Podobnie bowiem, jak rzeczy leżące blisko barwnych kolorów na skutek przenikającego światła ulegają zabarwieniu, tak samo ten, kto wyraźnie utkwił wzrok w Duchu, w pewien sposób dzięki Jego chwale ulega przemianie $\mathrm{w}$ coś bardziej promieniejącego, jakby jakimś światłem rozświetlając serce prawdą pochodzącą od Ducha. Oznacza to «być przekształconym przez chwałę Ducha we własną chwałę», nie w sposób nieznaczny i niewyraźny, lecz w takim stopniu, w jakim jest to słuszne dla istoty, którą Duch oświeca"10. W tej mierze, w jakiej serce przeniknięte jest Duchem, $\mathrm{w}$ takiej oświecone jest duchową światłością. Takie oświecenie, jest przemienieniem serca we „właściwej chwale” - na podobieństwo Świętego Ducha. Jest to oświecenie duchową światłością całego człowieka i całego stworzenia.

W traktacie O Duchu Świętym, Bazyli Wielki pisał: „Ku temu (tj. życiu w Bogu) zwraca się wszystko, co potrzebuje uświęcenia, do niego dąży wszystko, co żyje w czystości, aby się ochłodzić w [Jego] tchnieniu i ubezpieczyć się, każdy na swój własny naturalny koniec. Zdolny [On] jest nasycić innych, sam w niczym nie odczuwając braku; żyjący bez potrzeby pokrzepienia się, Sam prowadzi korowód życia; niepowiększający się przez stopniowe przyrosty, lecz od początku stanowiący pełnię; znajdujący się w Sobie samym, a równocześnie będący wszędzie. Źródło uświęcenia, światło rozjaśniające, które dostarcza z samego siebie wszelkiej istocie rozumnej jakby jakiejś jasności, by mogła ona odkryć prawdę"11. Z powyższego fragmentu wynika, że prawda Boga jest odkrywana przede wszystkim w sercu człowieka, które powinno ciągle się doskonalić oraz oczyszczać z namiętności i grzesznych przyzwyczajeń. Nie jest to jednak proste. Człowiek narażony jest w tym świecie na grzech. Czasem nawet nie potrafi go dostrzec, gdyż jego serce przepełnione jest grzesznymi namiętnościami. Człowiek, poprzez swoją grzeszność, stawia sercu przeszkody w zgłębianiu Bożej prawdy. Jednak pomocą $\mathrm{w}$ walce $\mathrm{z}$ grzechem jest post i modlitwa, która prowadzi serce człowieka do Boga.

W skutek grzechu, który „rozciął istnienie człowieka”" w sercu zaistniał podział. Serce stało się podzielone. $Z$ jednej strony bliskie mu jest dążenie do Boga, wychwalanie Go i zgłębianie Jego nauki. Z drugiej, przeszkodą stają się namiętności, pokusy oraz grzech. Serce jest w konflikcie samo ze sobą. Dążenie do zbawienia jest przerywane przez popełniane grzechy. Dlatego człowiek w zależności od moral-

\footnotetext{
9 Tamże, XXVI, 61, s. 170.

10 Tamże, XXI, 52, s. 158.

11 Tamże, IX, 22, s. 113.

12 К. Керн, Антропология..., dz. суt., s. 144.
}

nego stanu swoje życia postrzega swoje serce, jako jednolitą całość zwrócona tylko do Boga, albo obszar, który jest zróżnicowany sferą sacrum i profanum. Jednolitość serca przeczy jego zróżnicowaniu. Człowiek, który posiada jednolite serce dysponuje również zdolnością widzenia Jedynego Boga i odrzuca sprawy nieistotne z perspektywy zbawienia. Serce człowieka w całej swej pełni, jest znane tylko Bogu i tylko On może je przeniknąć. Jednak przed tym, jak człowiek osiągnie stan jednolitego serca, powinien wyzbyć się wszelkich namiętności i grzechów, które sprawiają, że jest ono zróżnicowane. Grzech jest stanem, w którym człowiek zapomina o Bogu i przestaje Go kochać. Jest to w pewien sposób odejście od Boga. Serce człowieka przesiąknięte jest złem i nie odczuwa potrzeby nawrócenia się.

Serce, które grzeszy, przestaje skupiać się na sprawach służących zbawieniu. Coraz bardziej popada w grzech, staje się złe i nie ma w nim bojaźni Bożej. Nie dopuszcza do siebie nauki Boga, która jest zbawienna. Takie serce przestaje być związane z umysłem, który stworzony został do przyjmowania pobożnych myśli.

Właściwością umysłu jest myślenie, które ma swoje źródło w sercu. Tak, jak dusza znajduje się w ciele, tak $\mathrm{i}$ wypowiadane słowo $\mathrm{z}$ początku znajduje się $\mathrm{w}$ sercu $^{13}$. Wewnętrzna mowa człowieka sprawiedliwego skierowana jest do Boga i dotyczy tylko Jego: „Wołają, a Pan wysłuchuje ich. I ocala ich ze wszystkich udręk" (Ps 34, 18). Wezwania ludzi sprawiedliwych są dokonywane w myślach, w sercu. Jednak są na tyle słyszalne przez Boga, że z czasem zostają spełnione. Ten, kto prosi o rzeczy wielkie i modli się o sprawy duchowe, niebiańskie, ten także kieruje swoje modlitwy do Boga, które zostają wysłuchane ${ }^{14}$.

Myślenie, które przepełnione jest przykazaniami Boży$\mathrm{mi}$, przejawia się na zewnątrz w dobrych słowach. „Dobry człowiek od dobrej skarbnicy swojego serca wynosi dobra" (Mt 12, 35). Serce człowieka, które przepełnione jest złem, przejawia się wypowiedziami, w których są złe sło$\mathrm{wa}^{15}$. Wypowiadane słowo powstaje $\mathrm{w}$ sercu, którego natura objawia się w jego treści.. „Nasze słowo ukazuje sobą całe nasze pojmowanie. Ponieważ to, co pomyśleliśmy w naszych sercach, to również wypowiedzieliśmy, to, co zostało wypowiedziane jest wizerunkiem zamysłów serca: dlatego słowo pochodzi z nadmiaru serca. Nasze serce jest swego rodzaju źródłem, a wypowiedziane słowo jest strumieniem wypływającym z tego źródła. Dlatego płynie tyle, ile wypłynęło z początku, to, co jest skryte, to samo zostaje z czasem ukazane ${ }^{16}$.

Na podobieństwo Słowa Bożego, słowo człowieka jest beznamiętnym wytworem umysłu, nie oddziela się od umysłu, lecz jest „pełnią" umysłu i zawiera w sobie "całą moc umysłu”. Dlatego, prośba proroka do Pana o uzdrowienie serca ludzkiego, posiada szybką odpowiedź na wysłuchanie prośby, którą jest - uzdrowienie ${ }^{17}$.

\footnotetext{
13 Рor. Василий Великий, Беседа 3. [w:] tamże, Москва 2000, s. 95.

14 Por. tenże, Пс. 33 (18), [w:] tegoż Беседы на Псалмы, dz. cyt., s. 39.

15 Tamże, Пc. 44 (2), s. 58.

16 Василий Великий, Беседа 16. На слова: В начале бе Слово (Ин. 1,1),

[w:] tamże, Москва 2000, s. 215.

17 Tamże, Пс. 29 (3), [w:] tegoż, Беседь на Псалмьы, dz. суt., s. 27.
} 
Grzeszny upadek człowieka wyrażał się w odstępstwie „prawego serca” od Boga w stronę grzechu i namiętności: „Jak linia staje się krzywą, gdy prosty kierunek zmieniał się w wypukłość, lub w wklęsłość, tak samo serce staje się krnąbrnym, kiedy to przyjmuje wyniosłą postawę. Dzięki uniżeniu jednak, do którego dochodzi się przez cierpienia oraz trudy, następuje zbawienie prawego serca. Prawe serce to takie, w którym rozsądek nie dopuszcza nadużyć, niedostatku w cnotach, lecz trzyma się środka. Kto od męstwa odstąpił, ten staje się bojaźliwym, a kto dopuścił się nadużyć, ten staje się grubiański” ${ }^{18}$. Grzeszny upadek zmienia rozumną naturę człowieka. Przez ludzkie zmysły zaczęły wchodzić także w duszę grzeszne myśli. Rozumne zdolności stały się „cielesnym mędrkowaniem”. Namiętności zaczęły prowadzić do zamętu, „niepokój duszy”. „Wzburzone serce” straciło zdolność „dostrzegania duchowej światłości prawdy", na podobieństwo zamglonego oka, które nie może właściwie zobaczyć rzeczywistości ${ }^{19}$.-Następstwem upadku serca w grzechu jest utrata kontaktu bezpośredniego z Bogiem. Człowiek jednak, może dzięki łasce Boga przywrócić ten pierwotny stan serca: „Gdyż ten, kto już nie żyje ciałem, lecz jest prowadzony przez Ducha Bożego, [kto] nazywa się synem Bożym i stał się podobny do obrazu Syna Bożego - ten nazywa się duchowym. Podobnie jak moc widzenia jest w zdrowym oku, tak działalność Ducha - w oczyszczonej duszy"20. Przywrócenie jednak tego pierwotnego stanu serca powinno być poprzedzone odrzuceniem grzesznych namiętności.

Nawiązując do grzesznych namiętności, święty Bazyli stwierdzał: „Kto ma upodobanie w pieniądzach, ten rozpala się zniszczalną, cielesną pięknością. Przekłada teraźniejszą sławę i wylewa moc swojej miłości na to, do czego nie należy dążyć, stając się tym samym ślepym w prawdziwym spoglądaniu na Umiłowanego"21. Człowiek, który odrzuca namiętności ze swego życia, tym samym wprowadza wielką zmianę w swoim sercu. Zmiana ta polega na odrzuceniu zła i wybraniu dobra.

Serce, w jego duchowym wymiarze jest podatne na zmiany na podobieństwo tego, jak ciało jest podatne na ciągłe zmiany, znajdując się w ciągłym ruchu i przekształceniach. Człowiek stale zmienia się duchowo, „zmieniając swoje myśli" w zależności od tego, co go w życiu spotyka. Myśl określa stan serca. Myśli gniewu i pożądania powodują, że serce wchodzi w stan grzeszny. Natomiast myśl o zmartwychwstaniu i życiu wiecznym, powoduje zmianę w „stan lepszy i duchowy”22. Zmiana myślenia zawiera się w dążeniu do przemiany serca. W odniesieniu do: (Ps 32, 11), święty Bazyli wspominał o nietrwałości i braku pożytku ludzkich nauk w obliczu prawdziwej Ewangelii. Człowiek, pragnący odzyskać zdolności słuchania przykazań Boga, powinien dążyć ku oczyszczeniu serca od myśli w tym ziemskim wymiarze: „Wiele zamysłów jest w sercu ludzkim, lecz rada Pana jest przezwyciężająca. I jeśli rada

\footnotetext{
8 Tamże, Пс. 7 (11), [w:] tegoż, Беседы на Псалмы, dz. суt., s. 17.

19 Tamże, Пс. 33 (3-4), [w:] tegoż, Беседь на Псалмьь, dz. суt., s. 34.

20 Bazyli Wielki, O Duchu Świętym, XXVI, 61, [w:] tamże, dz. cyt., s. 170.

21 Tenże, Беседь на Псалмы. Пс. 44.(1), [w:] tegoż, Москва 2000, s. 45.

22 Tamże, Пc. 44(1), s. 45.
}

Boga ciągle i skutecznie przebywa w duszach naszych, koniecznie przedtem należy zniszczyć $\mathrm{w}$ nas myśli $\mathrm{w}$ ziemskim wymiarze. Kto chce pisać na wosku, z początku musi nastąpić wygładzenie wosku, a potem naniesienie wybranych przez siebie wyobrażeń. Tak i w sercu, na którym odbite zostały jasno słowa Boże, trzeba stać się czystym od przeciwnych myśli”23. Wizerunek woskowej tabliczki objaśnia serce, jako plastyczną substancję, zmieniającą się w zależności od myśli, której jest ona nosicielem.

Do zmiany ludzkiego myślenia, niewystarczalne są tylko ludzkie dążenia. Sercu brakuje swoich sił, aby zachować w sobie „stan stanowczości” w trudnych sytuacjach życiowych. Serce, które osłabione jest niedowiarstwem i odstępstwami przyjmuje do siebie namiętności. Stanowczość oraz męstwo, otrzymuje ono, dzięki ufności w Bogu. Takie właśnie serce posiadał m.in. Hiob: „, ten niepokonany asceta, który wszystkie pokusy diabła, niczym płynący potok odparł, z niezachwianym sercem oraz stanowczym rozsądkiem. Pokazał on, że jest ponad pokusami, ponad trudnymi walkami, na które go wystawiał wróg. Czy serce Hioba nie było nieugiętym? Czy jego wnętrze nie było wykonane $\mathrm{z}$ kamienia? (...). On nie płakał, nie wyrywał włosów z głowy, nie wydobywał z siebie nie męskiego głosy, lecz wznosił to chwalebne i przez wszystkich wypowiadane dziękczynienie: Pan daje, Pan zabiera, jak Pan postanowi, tak i będzie, niech będzie błogosławione imię Pana" (Hi 1, 21) $)^{24}$.

Moc ufności w Bogu na tyle wznosi serce, że przestaje ono oddawać się grzesznym pokusom. W objaśnieniu Psalmu 46: „Przeto się nie boimy, choćby ziemia zadrżała. I góry zachwiały się w głębi mórz" (Ps 46, 3). Święty Bazyli ukazuje „wielką pewność ufności w Chrystusie” - nie zrażanie się niczym co się zdarza w życiu. Według proroka: „u kogo serce jest nieustraszone, u tego myśli nie są niczym zmącone"25.

Do najważniejszej zmiany serca prowadzi nieprzerywalne doskonalenie się w swoim życiu: „dla czyniącego postępy w dążeniu do cnót nie ma momentu, w którym by on się nie zmieniał"26. Doskonalenie się serca i unikanie grzechu następuje w pokorze i cierpieniu. „Duchowe rozdrażnienie" ukrócone zostaje cierpieniem, natomiast wyniosłość - pokorą. Kiedy „przykrości sprawdzają serce, jak złoto, które jest w ogniu", w cierpieniu ukazywane jest ich dobro ${ }^{27}$. Skrucha prowadzi do zniweczenia grzesznych myśli. Kto wzgardził rzeczami teraźniejszymi, oddał siebie słowom Bożym, ten posiadał będzie skruszone serce i sprawi, że stanie się ono ofiarą dla Pana. Sercem skruszonym i pokornym Bóg nie wzgardzi (Ps 50, 19) ${ }^{28}$. Pokorni duchem ludzie zaskarbiają łaskę Świętego Ducha i dobrowolnie stają się pokorni przed innymi, stając się tym samym pierwszymi w Królestwie Niebiańskim.

\footnotetext{
23 Tenże, Беседы на Псалмы. Пс. 32(11), [w:] tegoż, Москва 2000, s. 28.

24 Tenże, Беседа 4. О Благодарении., [w:] tegoż, Москва 2000, s. 105.

25 Tenże, Беседы на Псалмы. Пс. 45(3), [w:] tegoż, Москва 2000, s. 48.

26 Tamże, Пc. 44 (1), s. 44.

27 Tenże, Беседа 6. На слова из Евангелия от Луки (12:18), [w:] tegoż, Москва 2000, s. 122.

28 Tenże, Беседы на Псалмы. Пс.33(19), [w:] tegoż, Москва 2000, s. 39.
} 
Przemiana serca przedstawiona jest, jako zdolność odkrywania w sobie sfery duchowej. „Zatwardziałość serca" ukazana jest, jako serce, które zwrócone jest w kierunku grzesznych spraw. „Zmiękczyć zatwardziałe serce” może jedynie cierpienie za wyrządzone zło. Tak jak Eliasz wstrzymał deszcz nieprawemu narodowi na trzy lata i sześć miesięcy, dlatego też powstał głód, który został odpokutowany postem praktykowanym przez cały naród (Jk. 5,17). Post ten był konieczny, aby przemienić swoje życie od namiętności rozkoszy i rozpustnego życia „niepohamowane zatwardziałe serca"29. W objaśnieniu do fragmentu z Psalmu 60: „Lud swój wystawiłeś na ciężką próbę, Napoiłeś nas winem odurzającym" (Ps 60, 5), święty Bazyli ukazał ważną rolę istoty cierpień. Bóg prowadzi człowieka do Królestwa Bożego. Oczyszczając go od zła, przynosi Jednorodzonego Syna w ofierze za grzechy ludzi. W ofierze Syna jest możliwość wybawienia od grzechu, o czym dowiadujemy się z Pisma Świętego (1J 1,7).

Moc słów Biblii jest na tyle wielka, że „psalm z kamiennego serca wymusza łzy"30. Słowa Pisma Świętego rodzą w sercu misterium wiary. Dusza, przyjąwszy wiarę i rozpaliwszy serce miłością do Boga, powoduje, że staje się wrażliwą i zdolną do przyjęcia Bożych pouczeń. Miłość, wiąże serce z Bogiem, sprawiając, że staje się ono zdolnym do „ujrzenia miłości prawdziwego dobra”31. Doskonalenie się w miłości, nie dopuszcza do rozdzielenia miłości na pozostałe przedmioty: „Będziesz tedy miłował Pana, Boga swego, z całego serca swego i z całej duszy swojej, i z całej myśli swojej, i z całej siły swojej” (Mk 12, 30). Ponieważ powiedziano: „Kto ma oblubienicę, ten jest oblubieńcem;

29 Tenże, Две беседь о посте. Беседа 1-я, [w:] tegoż, Москва 1911, s. 82.

30 Tenże, Беседы на Псалмы. Пс.19 (1), [w:] tenże, Москва 2000, s. 24.

31 Tamże, Пc. 44 (6), s. 45. a przyjaciel oblubieńca, który stoi i słucha go, raduje się niezmiernie, słysząc głos oblubieńca. Tej właśnie radości doznaję w całej pełni”. (J 3, 29), to znaczy, że kto posiada stabilną i niezachwianą miłość do Chrystusa, ten jest dostojny Jego przyjaźni (...), a wszelki ten, który jest zepsuty i ignorancki - jest nieprzyjacielem. Dlatego, że przyjaźń nie łączy się ze złym stanem serca"32 - wyjaśniał święty Bazyli.

Miłość do Boga rodzi się w sercu i jest owocem rozmyślania o Nim. Taka myśl posiada wyjątkowy charakter: „Jeżeli kiedyś w twoim sercu poczujesz się tak, jakby wpadała do niego światłość, która wprowadzi nagłą myśl o Bogu i ogarnie twoją duszę, tak że pokochasz Boga, a ujrzawszy świat i wszystko co cielesne, dojdziesz do wniosku, że z tego słabego i małego podobieństwa poznałeś pełny stan sprawiedliwych, którzy równomiernie i bez przerwy wzrastają w radości o Bogu"33.

\section{Zakończenie}

Podsumowując, można stwierdzić, że święty Bazyli Wielki interpretował serce, jako rozumną duszę, która została stworzona według obrazu Bożego. Z początku dusza dysponowała wyjątkowymi zdolnościami. W człowieku serce ukazuje wrodzone dążenie do związku z Bożą miłością, z Duchem Świętym. Na skutek poświęcania się cielesnym namiętnością serce traci duchowe zdolności. Jednak poprzez przemianę serca, dusza dostępuje synergii z Bogiem. Miłość, która przepełnia serce człowieka zbliża duszę do Ducha Świętego i odnawia w sobie obraz Boga.

\footnotetext{
32 Tamże.

33 Tamże, Пc. 32 (1), s. 36.
}

\section{Bibliografia}

Biblia to jest Ksiegi Starego i Nowego Testamentu. Nowy przekład $z$ języków hebrajskiego i greckiego opracowany przez Komisje Przekładu Pisma, Warszawa 1990.

Bazyli Wielki, O Duchu Świętym, tł. A. Brzóstkowska, Instytut Wydawniczy"Pax", Warszawa 1999.

Drączkowski F., Patrologia, Wydawnictwo Pelplin, Lublin 2012.

Василий Великий свт., Беседа 3. На слова: внемли себе, [w:] Творения иже во святыхъ отияа нашего Василия Великаго, Архиепископа Кесарии Каппадокийския, Новый исправленный переводъ Московской Духовной Академии, Томъ II, Книгоиздательство П. П. Сойкина, Москва 2000, s. 91-99.

Василий Великий свт., Беседа 4. О Благодарении, [w:] Творения иже во святыхъ отия нашего Василия Великаго, Архиепископа Кесарии Каппадокийския, Новый исправленный переводъ Московской Духовной Академии, Томъ II, Книгоиздательство П. П. Сойкина, Москва 2000, s. 100-108.
Василий Великий свт., Беседа 6. На слова из Евангелия от Луки (12:18), [w:] Творения иже во святыхъ отиза нашего Василия Великаго, Архиепископа Кесарии Каппадокийския, Новый исправленный переводъ Московской Духовной Академии. Томъ II, Книгоиздательство П. П. Сойкина, Москва 2000, s. 119-126.

Василий Великий свт., Беседа 16. На слова: В начале бе Слово (Ин.1,1), [w:] Творения иже во святыхъ отияа нашего Василия Великаго, Архиепископа Кесарии Каппадокийския, Новый исправленный переводъ Московской Духовной Академии, Томъ II, Книгоиздательство П. П. Сойкина, Москва 2000, s. 214-219.

Василий Великий свт., Беседы на Псалмы, Московское Подворье Свято-Троицкой Сергиевой Лавры, 2000.

Василий Великий, свт., Беседы на Шестоднев. Беседа 10(7), [w:] Творения иже во святыхъ отия нашего Василия Великаго, Архиепископа Кесарии Каппадокийския, Новый исправленный переводъ Московской Духовной 
Академии, Томъ II, Книгоиздательство П. П. Сойкина, Москва 2000, s. 30-38.

Василий Великий, Две беседы о посте. Беседа 1-я, [w:] Творения иже во святыхъ отиа натего Василия Великаго, Архиепископа Кесарии Каппадокийския, Новый исправ- ленный переводъ Московской Духовной Академии, Томъ II, Книгоиздательство П. П. Сойкина, Москва 2000, s. 76-85.

Керн К, архим., Антропология Св. Григория Паламы, Изд. YMCA-Press Париж 1950.

Rozmiar artykułu: 0,8 arkusza wydawniczego 